\title{
EFFECTS OF ROSUVASTATIN IN EXPERIMENTALLY- INDUCED CARDIAC ISCHEMIA AND ON AORTIC VASCULAR REACTIVITY. BY
}

\author{
Maryam M. Hamouda, Dr. Zeinab Abbas Abd El Baki, Dr. Faten Ahamed Youssef, \\ Dr. Marwa Abdel Moneim El Kholy
}

\section{FROM}

Department of Pharmacology, Faculty of Medicine, Al-Az har University, Cairo. \begin{abstract}
:
Myocardial infarction (MI) continues to be a major public health problem in the world. The present study aimed to elucidate the protective effect of different doses of rosuvastatin and cilostazol, as well as their combination on isoprenaline-induced MI in rats as well as their effects on isolated aorta. Methods: I- Adult rats received different doses of rosuvastatin $(1,2,5,10, \& 20 \mathrm{mg} / \mathrm{kg})$, cilostazol $(18 \mathrm{mg} / \mathrm{kg})$ and combination of rosuvastatin $1 \mathrm{mg} / \mathrm{kg}$ and cilostazol $18 \mathrm{mg} / \mathrm{kg}$ by oral gavage daily for 16 days, then rats were subcutaneously injected with two doses $24-\mathrm{h}$ apart of $150 \mathrm{mg} / \mathrm{kg}$ isoprenaline in the last two days. ECG pattern was monitored, myocardial injury markers (CK-MB and $\mathrm{LDH}$ ) and inflammatory biomarker (CRP) were measured in serum. MDA, catalase and SOD were quantified in cardiac homogenates and heart tissue damage was examined by histopathology. II- Effects of rosuvastatin $(0.2 \mu \mathrm{g} / \mathrm{ml}-6.4 \mu \mathrm{g} / \mathrm{ml})$, cilostazol $(7.5 \mu \mathrm{g} / \mathrm{ml}-$ $480 \mu \mathrm{g} / \mathrm{ml})$ and combination cilostazol $(30 \mu \mathrm{g} / \mathrm{ml})$ and rosuvastatin $(0.2 \mu \mathrm{g} / \mathrm{ml}-6.4 \mu \mathrm{g} / \mathrm{ml})$ on NE-induced contraction in rabbit aortic strip were recorded. Each dose of either rosuvastatin or cilostazol were incubated for $10 \mathrm{~min}$ and $15 \mathrm{~min}$ respectively then NE $(0.5$ $\mu \mathrm{g} / \mathrm{ml}$ ) was added and the contraction was recorded for one and half min. Results: IPretreatment with different doses of rosuvastatin $(1,2,5 \& 10)$, cilostazol $18 \mathrm{mg} / \mathrm{kg}$ and the combination markedly ameliorated ISO-induced alterations in ECG, cardiac markers, inflammatory marker, oxidative markers and heart architecture. However, protection disappeared at higher dose of rosuvastatin $20 \mathrm{mg} / \mathrm{kg}$. II- Addition of either rosuvastatin $(0.2-6.4 \mu \mathrm{g} / \mathrm{ml})$, cilostazol $(7.5-480 \mu \mathrm{g} / \mathrm{ml})$ or combination rosuvastatin $(0.2-6.4 \mu \mathrm{g} / \mathrm{ml})$ and cilostazol $30 \mu \mathrm{g} / \mathrm{ml}$ produced a significant decrease in the height of NE-induced contraction in a dose dependent manner. Conclusion: I-This study provides evidence that rosuvastatin, cilostazol and their combination possess cardioprotective effect on isoprenaline-induced myocardial infarction. II- The drugs had vasorelaxant effect on aorta. Mechanism of drug action are discussed.
\end{abstract}

\section{Introduction}

Acute myocardial infarction (AMI) is among the most prevalent health problems in the world, and is a major cause of morbidity and mortality (Abdikarim and Basgut, 2016). Isoprenaline (ISO) induced myocardial infarction is widely used experimental model for several reasons. The model is characterized by technical simplicity, an excellent reproducibility as well as an acceptable low mortality (Dhakad et al., 2017). Isoprenaline, a beta-adrenoceptor agonist, has been reported to produce MI in large doses. Subcutaneous injection of ISO causes imbalance between oxygen supply and demand by the cardiomyocytes through increasing the chronotropism and inotropism 
important to overt myocardial function and increase in the calcium overload in the myocardium (Lobo Filho et al., 2011).

Rosuvastatin is one of the most potent inhibitors of HMG-CoA reductase enzyme. Rosuvastatin, has an appreciable anti-atherogenic property which is due to the improvement of endothelial dysfunction as well as its anti-thrombotic, antiinflammatory and antioxidant effects (Rondi et al., 2014). Statins are among the drugs which can protect against myocardial ischemia-reperfusion injury (Balakumar and Mahadevan, 2012).

Antiplatelets are also used in the setting of myocardial infarction. Cilostazol a quinolinone-derivative is a phosphodiestrase inhibitors which increases the activity of cyclic adenosine monophosphate, it is used worldwide for the treatment of intermittent claudication with arterial vasodilator effect and antiplatelet activities (Bai et al., 2011).

So, in the present study we aimed to investigate the protective effect of different doses of rosuvastatin, cilostazol and their combination in cardiac ischemia to determine the most effective dose in protection of the heart. Parameters chosen to assess myocardial damage and protective effects of tested drugs included serum creatine kinase-MB (CK-MB), lactate dehydrogenase (LDH), C-reactive protein (CRP) levels as well as the determination of cardiac malondialdhyde (MDA) and antioxidants catalase and superoxide dismutase (SOD) content. In addition, ECG pattern and histopathological examination of heart tissues were performed.

\section{2-Materials and Methods}

\subsection{Animals}

The present study was performed on 108 adult male albino rats of local strain weighing 180-200 gms. Animals were purchased from local farm, in Abo Rawaash Farm (Egypt). They were housed in plastic cages and kept under suitable laboratory conditions that meet the guidelines of the Ethics Committee, Faculty of Medicine (for Girls), Al-Azhar University, Cairo.

\subsection{Drugs and chemicals}

\section{Rosuvastatin calcium}

(Crestor), Astra Zeneca Pharmaceutical Co, United Kingdom. Cilostazol (Pletal), Otsuka Pharmaceutical Company, Tokushima, Japan. Isoprenaline hydrochloride was purchased from Sigma-Aldrich (MO, USA); whereas Pentobarbiton sodium (Nembutol-Surva, USA), Norepinephrine tartarate-Tiba Pharmaceutical (Egypt).

\subsection{Induction of myocardial infarction}

MI was induced in rats by subcutaneous injection of $150 \mathrm{mg} / \mathrm{kg}$ isoprenaline hydrochloride dissolved in saline once daily for two successive days. It was conducted according to Lobo Filho et al. ( 2011).

\subsection{Experimental design and animal groups}

108 male albino rats were divided into 3 main groups

A- Non ischemic non treated group (12 rats), (control normal).

B- $\quad$ Ischemic non treated group (12 rats). 
C- Ischemic treated groups (84 rats).

Group C was divided into 7 subgroups of 12 rats each and were treated orally with different doses of rosuvastatin $(1,2,5,10 \& 20 \mathrm{mg} / \mathrm{kg}$ ) (Dourado et al., 2011 and Habibi et al., 2007), cilostazol (18mg/kg) cilostazol was chosen corresponding to the human therapeutic doses and was calculated according to the method given by Paget and Barnes. (1964), and combination of rosuvastatin $1 \mathrm{mg} / \mathrm{kg}$ and cilostazol $18 \mathrm{mg} / \mathrm{kg}$ once daily for 16 days. All groups except the non ischemic non treated one received isoprenaline $(150 \mathrm{mg} / \mathrm{kg}$; s.c.) in day $15 \& 16$ of the study. Twenty-four hours after the last treatment, animals were anesthetized with pentobarbiton sodium (30 mg/kg I.P.) for ECG monitoring. Thereafter, blood samples were collected from the retro-orbital plexus for serum separation and estimation of CK-MB, LDH and CRP level. Rats were then sacrificed by decapitation and the hearts were rapidly isolated, washed with ice-cold saline and were used for histopathological examination and estimation of MDA, and the antioxidants catalase and SOD in cardiac homogenate.

\subsection{ECG monitoring}

Anesthetized rats (6 rats) from each group were placed in the supine position on a suitable rodent wooden table. ECG electrodes were placed subcutaneously in the left foreleg, right foreleg, and left thigh respectively. Lead II ECG was recorded continuously with standard artifact free at a speed of $25 \mathrm{~mm} / \mathrm{second}$ provided that the recorded signals must be free of noise and electrical interference. The equipment used was the Power Lab Data Acquisition and Analysis systems (Power Lab 4/35 with Lab Chart Pro, animal Bio Amp. Model number FE136 AD Instruments, Australia).

\subsection{Biochemical assays}

The serum level of myocardial injury markers CK-MB and LDH were measured according to methods described by Okinaka et al. (1961) and King, (1965), using commercial kits and employing an automatic biochemistry analyzer (AU-2700, Olympus, Japan). The serum level of Inflammatory marker C-reactive protein was measured according to method described by Hutchinson et al. (2000), using specific immunoassay kit (Immunospec Corporation, CA, USA).

In the cardiac homogenate, malondialdehyde (MDA), an indicator of lipid peroxidation, was estimated according to method described by Ohkawa et al. (1979), using a standard kits (Jiancheng Bioengineering Institute ,Nanjing, China). Cardiac catalase and SOD content in heart homogenate were also estimated according to methods described by Caliborne. (1985), and Marklund and Marklund. (1974), using a standard kits (Jiancheng Bioengineering Institute, Nanjing, China).

\subsection{Histopathological examination}

At the end of drug treatment (day 16), ( 6 rats of each group), were sacrificed and the whole heart was rapidly dissected out, washed immediately with ice-cold normal saline and fixed in $10 \%$ formalin solution and cut into $5 \mu \mathrm{m}$ width. Paraffin sections were stained with hematoxylin and eosin (H\&E) and were examined under light microscope. 


\subsection{Isolated rabbit aortic spiral strip.}

Effects of rosuvastatin $(0.2 \mu \mathrm{g} / \mathrm{ml}-6.4 \mu \mathrm{g} / \mathrm{ml})$, cilostazol $(7.5 \mu \mathrm{g} / \mathrm{ml}-480 \mu \mathrm{g} / \mathrm{ml})$ and combination of cilostazol $(30 \mu \mathrm{g} / \mathrm{ml})$ and rosuvastatin $(0.2 \mu \mathrm{g} / \mathrm{ml}-6.4 \mu \mathrm{g} / \mathrm{ml})$ on $\mathrm{NE}$ induced contraction.

Rabbits of both sexes weighing $1.5-2 \mathrm{~kg}$ was sacrificed and the chest was opened. The aorta was immediately excised and transferred to a Petri-dish containing freshly prepared oxygenated Krebs solution ( $\mathrm{NaCl} 6.92, \mathrm{KCl} 0.35, \mathrm{MgSo} 40.29, \mathrm{CaCl} 2$ $0.28, \mathrm{KH} 2 \mathrm{PO} 40.16, \mathrm{NaHCO} 32.10$ and glucose $2.00 \mathrm{~g} / \mathrm{L}$ ). The vessel was then cleared by trimming any fat and connective tissue before being cut spirally to produce a continuous strip about $4 \mathrm{~mm}$ wide and 3 to $4 \mathrm{~cm}$ long. The preparation was suspended in a $20 \mathrm{ml}$ palmer organ-bath containing Krebs solution at $37^{\circ} \mathrm{C}$ and aerated with carbogen $(95 \% \mathrm{O} 2+5 \% \mathrm{CO} 2)$. The preparation was left $1-2 \mathrm{hrs}$ for stabilization and adaptation to the in vitro experimental conditions. Effect of rosuvastatin $(0.2 \mu \mathrm{g} / \mathrm{ml}-6.4$ $\mu \mathrm{g} / \mathrm{ml})$, cilostazol $(7.5 \mu \mathrm{g} / \mathrm{ml}-480 \mu \mathrm{g} / \mathrm{ml})$ and combination of cilostazol $(30 \mu \mathrm{g} / \mathrm{ml})$ and rosuvastatin $(0.2 \mu \mathrm{g} / \mathrm{ml}-6.4 \mu \mathrm{g} / \mathrm{ml})$ on NE-induced contraction was performed. Each dose of either rosuvastatin or cilostazol was incubated for $10 \mathrm{~min}$ and $15 \mathrm{~min}$ respectively according preliminary study, then $\mathrm{NE}(0.5 \mu \mathrm{g} / \mathrm{ml})$ was added and the contraction was recorded for one and half min.

\subsection{Site of action of either rosuvastatin or cilostazol}

The vasorelaxant response to either rosuvastatin $(3.2 \mu \mathrm{g} / \mathrm{ml})$ or cilostazol $(240$ $\mu \mathrm{g} / \mathrm{ml}$ ) was assessed in aortic strips pre-incubated with inhibitors or blockers for 30 min. The vasorelaxant effect was investigated before and after pre-incubation with the following: (i) 50, $100 \& 150 \mu \mathrm{g} / \mathrm{ml}$ L L-NAME (a non-selective NOS inhibitor) (ii) $8 \&$ $16 \mu \mathrm{g} / \mathrm{ml}$ indomethacin ( a prostaglandin synthesis inhibitor,; or (iii) $0.8 \& 1.6 \mu \mathrm{g} / \mathrm{ml}$ glibenclamide ( ATP activated $\mathrm{K}+$ channel blocker)

\subsection{Statistical analysis}

Data were expressed as mean \pm SEM. Comparisons between means of different groups were carried out using one-way analysis of variance (ANOVA) followed by Post hoc Tukey multiple comparisons test. The level of significance was taken as $p<0.05$.

\section{Results}

3.1. Effect of rosuvastatin $(1,2,5,10 \& 20 \mathrm{mg} / \mathrm{kg})$, cilostazol $(18 \mathrm{mg} / \mathrm{kg})$ and combination of rosuvastatin $1 \mathrm{mg} / \mathrm{kg} \&$ cilostazol $18 \mathrm{mg} / \mathrm{kg}$ on ECG record in isoprenaline induced myocardial infarction in rats.

Subcutaneous injection of isoprenaline $(150 \mathrm{mg} / \mathrm{kg})$ for two successive days induced MI represented by significant increase of ST segment elevation and decreased in heart rate in ischemic group as compared with non ischemic group. Pretreatment with rosuvastatin $(1,2,5,10 \& 20 \mathrm{mg} / \mathrm{kg})$, cilostazol and the combination resulted in a significant reduction in ST segment elevation and a significant increase in heart rate as compared with ischemic non treated group. Comparison between the mean values of heart rate between ischemic drug-treated groups with that of non ischemic non-treated group revealed insignificant difference, only with rosuvastatin $2 \& 5 \mathrm{mg} / \mathrm{kg}$ and the combination of rosuvastatin and cilostazol (Fig. 1). 


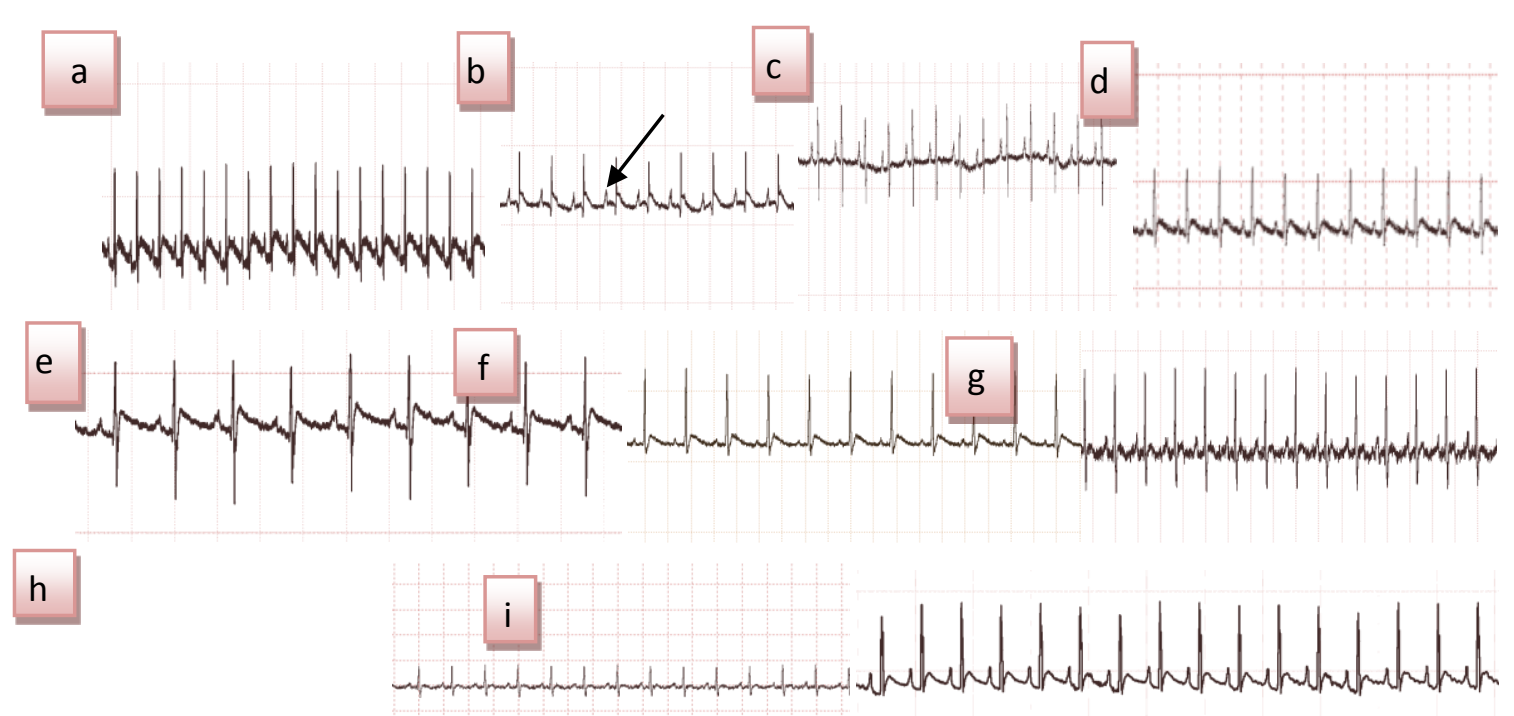

Fig. (1): ECG records: (a) non ischemic rat showing normal pattern of ECG waves, rhythm and heart rate, (b) an ischemic non treated rat showing ST segment elevation (arrow), a sign of myocardial infarction, a decrease of heart rate is also apparent, (c-g) ischemic rats pretreated with rosuvastatin, showing restoration of ECG pattern and normalization of ST segment elevation mainly evident with $1,2,5 \& 10 \mathrm{mg} / \mathrm{kg}$ and less apparent with $20 \mathrm{mg} / \mathrm{kg}$, (h \& i ):- ischemic rat pretreated with either cilostazol $(18 \mathrm{mg} / \mathrm{kg}$ ) alone $(\mathrm{h})$ or in combination with rosuvastatin $1 \mathrm{mg} / \mathrm{kg}$ (i) showing restoration of normal ECG waves, rhythm and heart rate.

3.2. Effect of pretreatment with rosuvastatin $(1,2,5,10 \& 20 \mathrm{mg} / \mathrm{kg})$, cilostazol $(18 \mathrm{mg} / \mathrm{kg})$ and combination of rosuvastatin $1 \mathrm{mg} / \mathrm{kg} \&$ cilostazol $18 \mathrm{mg} / \mathrm{kg}$ on myocardial injury markers and inflammatory marker. Serum CK-MB, LDH and CRP showed significantly higher levels in ischemic nontreated group as compared with the non ischemic group. Pretreatment of ischemic rats with rosuvastatin $(1,2,5 \& 10 \mathrm{mg} / \mathrm{kg})$, cilostazol and the combination produced a significant decrease in $\mathrm{CK}$ MB, LDH \& CRP serum levels as compared with ischemic non-treated group. On the other hand, pretreatment with rosuvastatin in a dose of $20 \mathrm{mg} / \mathrm{kg}$ insignificantly decreased serum CK-MB, LDH \& CRP levels as compared with ischemic non-treated group. The reduction produced by the combination of both drugs was significantly more than that produced by either drug alone. Comparison between the mean values of $\mathrm{CK} \mathrm{MB}, \mathrm{LDH} \& \mathrm{CRP}$ in the different ischemic pretreated groups with that of non ischemic non-treated group revealed insignificant difference only with rosuvastatin $2 \& 5 \mathrm{mg} / \mathrm{kg}$ and also with the combination of rosuvastatin and cilostazol (Table 1 \& Fig. 2).

3.3. Effect of pretreatment with rosuvastatin $(1,2,5,10 \& 20 \mathrm{mg} / \mathrm{kg})$, cilostazol $(18 \mathrm{mg} / \mathrm{kg}$ ) and combination of rosuvastatin $1 \mathrm{mg} / \mathrm{kg} \&$ cilostazol $18 \mathrm{mg} / \mathrm{kg}$ on oxidative stress markers.

Compared with non ischemic group, ischemic non-treated group showed a significant elevation in cardiac MDA and decreased cardiac catalase and SOD contents. Pretreatment of ischemic rats with rosuvastatin $(1,2,5 \& 10 \mathrm{mg} / \mathrm{kg})$, cilostazol and the combination produced a significant reduction in cardiac MDA content and a significant increase in cardiac contents of catalase and SOD as compared with ischemic non-treated group. However, pretreatment with rosuvastatin $20 \mathrm{mg} / \mathrm{kg}$ caused 
insignificant increase in cardiac contents of catalase and SOD but significantly decreased cardiac MDA content. The reduction in MDA and the increase in cardiac catalase content produced by the combination of both drugs was significantly more than that produced by either drugs alone. However, the comparison between the combination and rosuvastatin at doses $2 \& 5 \mathrm{mg} / \mathrm{kg}$ revealed insignificant difference. In addition, the group treated with the combination of rosuvastatin and cilostazol showed mean values comparable to and insignificantly different from that of non ischemic nontreated group (Table 1 \& Fig 3).

Table (1): Effect of pretreatment with rosuvastatin $(1,2,5,10,20 \mathrm{mg} / \mathrm{kg})$, cilostazol $(18 \mathrm{mg} / \mathrm{kg})$ and combination of rosuvastatin $1 \mathrm{mg} / \mathrm{kg} \&$ cilostazole $18 \mathrm{mg} / \mathrm{kg}$ on serum levels of $\mathrm{CK} \mathrm{MB}(\mathrm{ng} / \mathrm{ml}), \mathrm{LDH}(\mathrm{U} / \mathrm{ml})$ and $\mathrm{CRP}(\mathrm{ng} / \mathrm{ml}))$ and oxidative stress markers MDA (nmol/g tissue), catalase (U/g tissue) \& SOD (U/g tissue)) in isoprenaline $(150 \mathrm{mg} / \mathrm{kg})$ induced cardiac infarction in rats.

\begin{tabular}{|c|c|c|c|c|c|c|}
\hline & \multicolumn{3}{|c|}{ Serum markers } & \multicolumn{3}{|c|}{ Oxidative stress markers } \\
\hline & CK MB & LDH & CRP & MDA & Catalase & SOD \\
\hline $\mathbf{N}$ & $3.58 \pm 0.32 ¥$ & $52.5 \pm 2.81 ¥$ & $2.10 \pm 0.25 ¥$ & $4.43 \pm 0.53 ¥ \bullet$ & $9.9 \pm 0.79 ¥ \bullet$ & $9.02 \pm 0.38 ¥ \bullet \dagger €$ \\
\hline INT & $\begin{array}{c}16.45 \pm 0.52 \\
€\end{array}$ & $\begin{array}{c}251.67 \pm 16.61 \\
\bullet € €\end{array}$ & $\begin{array}{c}14.45 \pm 0.70 \\
€\end{array}$ & $54.50 \pm 2.88 \bullet \dagger €$ & $\begin{array}{c}1.87 \pm .020 \\
€\end{array}$ & $1.63 \pm 0.16 \bullet \dagger €$ \\
\hline $\begin{array}{c}\text { Ros. } \\
\text { 1mg/kg }\end{array}$ & $\begin{array}{c}9.97 \pm 0.32 ¥ \bullet \dagger \\
€\end{array}$ & $\begin{array}{c}146.0 \pm 5.22 ¥ \\
\dagger €\end{array}$ & $\begin{array}{c}8.07 \pm 0.59 ¥ \bullet \dagger \\
€\end{array}$ & $18.17 \pm 0.57 ¥ €$ & $\begin{array}{c}5.48 \pm 0.27 ¥ \\
\dagger €\end{array}$ & $5.90 \pm 0.28 ¥ \dagger €$ \\
\hline $\begin{array}{c}\text { Ros. } \\
\text { 2mg/kg }\end{array}$ & $3.85 \pm 0.20 ¥$ & $69.5 \pm 2.14 ¥$ & $3.55 \pm 0.22 ¥$ & $16.75 \pm 0.63 ¥ €$ & $7.27 \pm 0.43 ¥ €$ & $6.27 \pm 0.30 ¥ \dagger €$ \\
\hline $\begin{array}{c}\text { Ros. } \\
\text { 5mg/kg }\end{array}$ & $4.80 \pm 0.33 ¥$ & $76.17 \pm 4.39 ¥$ & $3.63 \pm 0.22 ¥$ & $15.50 \pm 0.61 ¥ €$ & $7.98 \pm 0.36 ¥ €$ & $7.73 \pm 0.24 ¥ \bullet €$ \\
\hline $\begin{array}{c}\text { Ros. } \\
\text { 10mg/k } \\
\text { g }\end{array}$ & $\begin{array}{c}8.40 \pm 0.20 ¥ \bullet \dagger \\
€\end{array}$ & $\begin{array}{c}134.33 \pm 11.11 \\
¥ \bullet \dagger €\end{array}$ & $\begin{array}{c}7.78 \pm 0.33 ¥ \bullet \dagger \\
€\end{array}$ & $21.93 \pm 1.20 ¥ €$ & $\begin{array}{c}5.12 \pm 0.28 ¥ \\
\dagger €\end{array}$ & $4.70 \pm 0.23 ¥ \bullet \dagger €$ \\
\hline $\begin{array}{c}\text { Ros. } \\
20 \mathrm{mg} / \mathrm{k} \\
\mathrm{g}\end{array}$ & $\begin{array}{c}14.43 \pm 0.81 \\
€\end{array}$ & $\begin{array}{c}222.17 \pm 15.41 \\
\diamond \dagger €\end{array}$ & $\begin{array}{c}12.62 \pm 0.52 \\
€\end{array}$ & $40.77 \pm 3.23 ¥ \bullet \dagger €$ & $\begin{array}{c}3.20 \pm 0.16 \bullet \dagger \\
€\end{array}$ & $2.30 \pm 0.16 \bullet \dagger €$ \\
\hline $\begin{array}{c}\text { Cilo } \\
\text { 18mg/k } \\
\text { g }\end{array}$ & $\begin{array}{c}8.98 \pm 0.38 ¥ \bullet \dagger \\
€\end{array}$ & $\begin{array}{c}117.83 \pm 4.06 ¥ \\
\bullet \dagger €\end{array}$ & $\begin{array}{c}6.97 \pm 0.33 ¥ \bullet \dagger \\
€\end{array}$ & $23.15 \pm 0.80 ¥ \dagger €$ & $\begin{array}{c}3.92 \pm 0.14 ¥ \\
\dagger €\end{array}$ & $3.97 \pm 0.15 ¥ \bullet \dagger €$ \\
\hline $\begin{array}{c}\text { Cilo. } \\
\text { \&Ros. } \\
\text { 1mg/kg }\end{array}$ & $2.63 \pm 0.32 ¥$ & $41.0 \pm 3.61 ¥$ & $1.78 \pm 0.25 ¥$ & $12.20 \pm 0.69 ¥ €$ & $8.88 \pm 0.28 ¥$ & $7.50 \pm 0.43 € ¥$ \\
\hline
\end{tabular}

$\mathbf{N}=$ Non ischemic $\quad$ INT $=$ Ischemic non treated $\mathbf{R o s} .=$ Rosuvastatin

Cilo.

$$
=\text { Cilostazol }
$$

$¥=$ Significant as compared to INT

$\checkmark=$ Significant as compared to rosuvastatin

$2 \mathrm{mg} / \mathrm{kg}$ 
$\dagger=$ Significant as compared to rosuvastatin $5 \mathrm{mg} / \mathrm{kg} \quad €=$ Significant as compared to non ischemic $(\mathrm{N})$

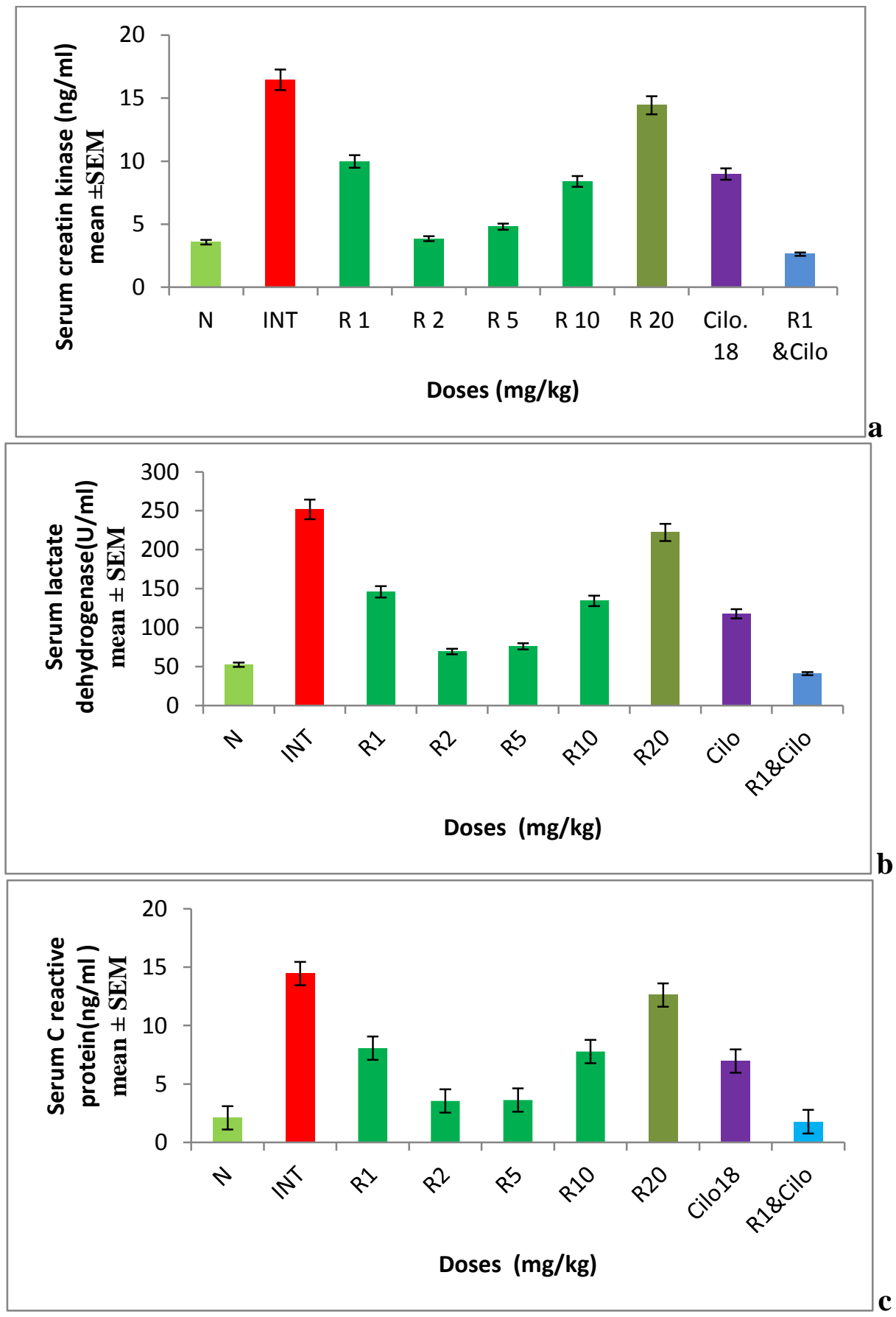

Fig. (2): Bar chart showing the effect of pretreatment with rosuvastatin $(1,2,5,10,20$ $\mathrm{mg} / \mathrm{kg})$, cilostazol $(18 \mathrm{mg} / \mathrm{kg}$ ) and combination of rosuvastatin $1 \mathrm{mg} / \mathrm{kg} \&$ cilostazole $18 \mathrm{mg} / \mathrm{kg}$ on serum levels of creatin kinase $\mathrm{MB}$, lactate dehydrogenase and $\mathrm{C}$ reactive protein in isoprenaline $(150 \mathrm{mg} / \mathrm{kg})$ induced myocardial infarction in rats. 
$\mathrm{N}=$ Non ischemic INT=Ischemic non-treated $\quad \mathrm{R} 1-\mathrm{R} 20=$ Rosuvastatin doses (1$20 \mathrm{mg} / \mathrm{kg}$ ) Cilo. $=$ Cilostazol
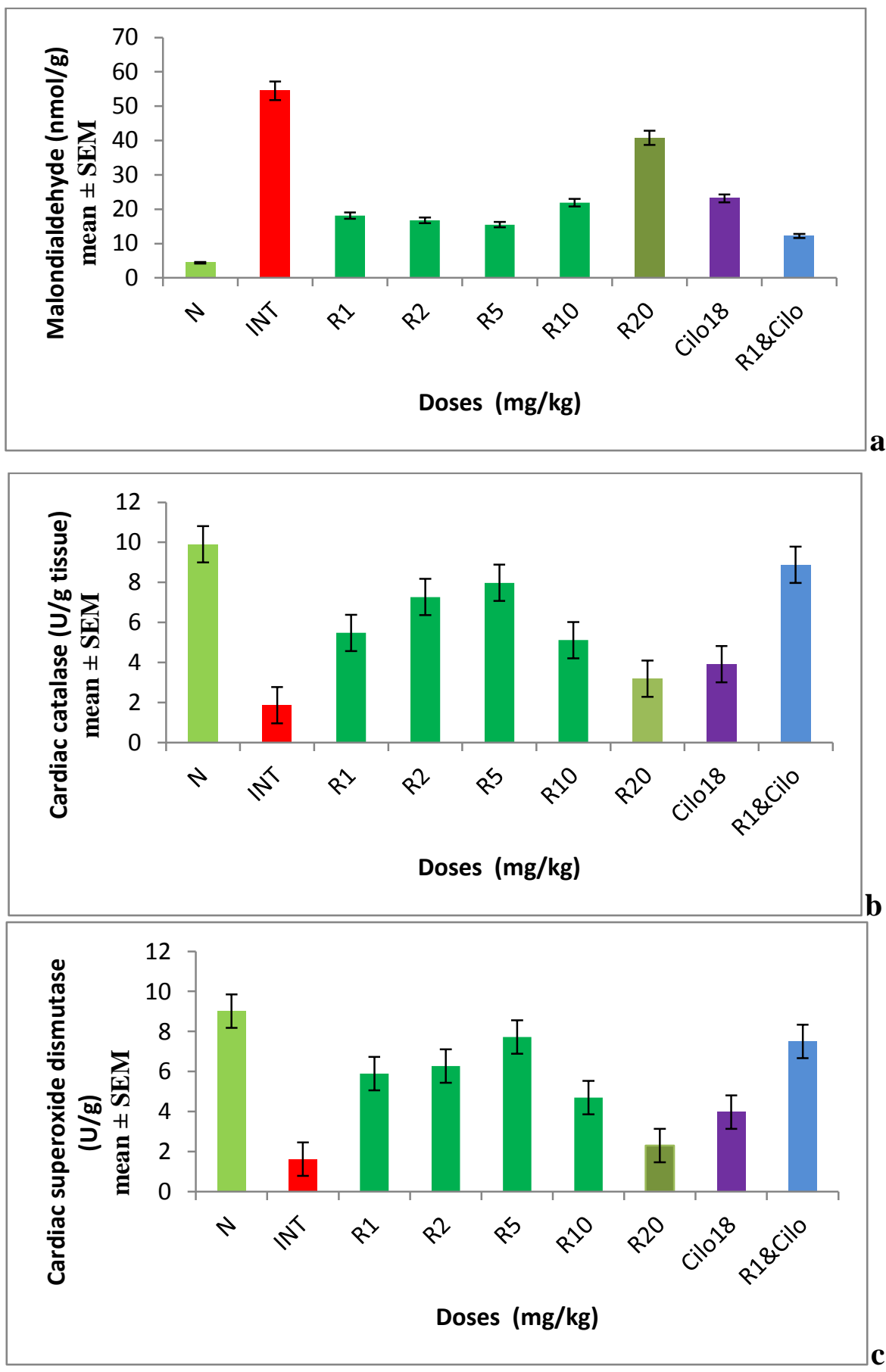

Fig. (3): Bar chart showing the effect of pretreatment with rosuvastatin $(1,2,5,10,20$ $\mathrm{mg} / \mathrm{kg}$ ), cilostazol $(18 \mathrm{mg} / \mathrm{kg}$ ) and combination of rosuvastatin $1 \mathrm{mg} / \mathrm{kg}$ \& cilostazol $18 \mathrm{mg} / \mathrm{kg}$ on cardiac contents of malondialdehyde, catalase and superoxide dismutase in isoprenaline $(150 \mathrm{mg} / \mathrm{kg})$ induced cardiac infarction in rats. 
$\mathrm{N}=$ Non ischemic INT=Ischemic non-treated R1-R20=Rosuvastatin doses (1$20 \mathrm{mg} / \mathrm{kg}$ ) Cilo. $=$ Cilostazol

3.4. Effect of pretreatment with rosuvastatin $(1,2,5,10 \& 20 \mathrm{mg} / \mathrm{kg})$, cilostazol $(18 \mathrm{mg} / \mathrm{kg})$ and combination of rosuvastatin $1 \mathrm{mg} / \mathrm{kg} \&$ cilostazol $18 \mathrm{mg} / \mathrm{kg}$ on histopathological examination of the heart.

Microscopic examination of heart sections from ischemic non treated group revealed marked myofibrillar degeneration, loss of transverse striations, infiltration of inflammatory cells, and extravasations of red blood cells. Ischemic rats pretreated with rosuvastatin $1 \& 10 \mathrm{mg} / \mathrm{kg}$ or cilostazol $18 \mathrm{mg} / \mathrm{kg}$ revealed moderate improvement with focal areas of necrosis and mild infiltration of inflammatory cells, as well as pretreatment of ischemic rats with rosuvastatin $20 \mathrm{mg} / \mathrm{kg}$ shown mild improvement with focal areas of necrosis, severe infiltration of inflammatory cells and extravasations of red blood cells. On the other hand, microscopic examination of heart sections from ischemic rats pretreated with rosuvastatin $2 \& 5 \mathrm{mg} / \mathrm{kg}$ or with the combination revealed marked improvement evident by appearance normal architecture of heart tissue (with one centrally placed nucleus) and absence of inflammatory cells infiltration or extravasation of blood (Fig. 4). The histopathological examination of all groups were scored and graded on the basis of severity of histopathological changes as shown in Table (2).

Table (2):- Effect of pretreatment rosuvastatin $(1,2,5,10 \& 20 \mathrm{mg} / \mathrm{kg})$, cilostazol $(18 \mathrm{mg} / \mathrm{kg})$ and combination of rosuvastatin $(1 \mathrm{mg} / \mathrm{kg})$ \& cilostazol $(18 \mathrm{mg} / \mathrm{kg})$ on histopathological changes in isoprenaline-induced myocardial infarction in rats.

\begin{tabular}{|c|c|c|c|}
\hline Group & $\begin{array}{l}\text { Myofibrillar } \\
\text { necrosis }\end{array}$ & Inflammation & $\begin{array}{l}\text { Extravsation of } \\
\text { blood }\end{array}$ \\
\hline Normal & ---- & ---- & +-- \\
\hline $\begin{array}{c}\text { Isoprenaline-induced } \\
\text { MI }\end{array}$ & +++ & +++ & + \\
\hline Ros $1 \mathrm{mg} / \mathrm{kg}$ & + & + & -- \\
\hline Ros $2 \mathrm{mg} / \mathrm{kg}$ & --- & --- & --- \\
\hline Ros $5 \mathrm{mg} / \mathrm{kg}$ & --- & --- & + \\
\hline Ros $10 \mathrm{mg} / \mathrm{kg}$ & + & + & ++ \\
\hline Ros $20 \mathrm{mg} / \mathrm{kg}$ & ++ & +++ & + \\
\hline Cilo $18 \mathrm{mg} / \mathrm{kg}$ & + & + & -- \\
\hline Comb. & --- & -- & + \\
\hline
\end{tabular}

Ros $=$ Rosuvastatin $\quad$ Cilo $=$ Cilostazol $\quad$ Comb $=$ Combination

(+) Mild, (++) Moderate, (+++) Severe; $\quad$ (---) nil. 


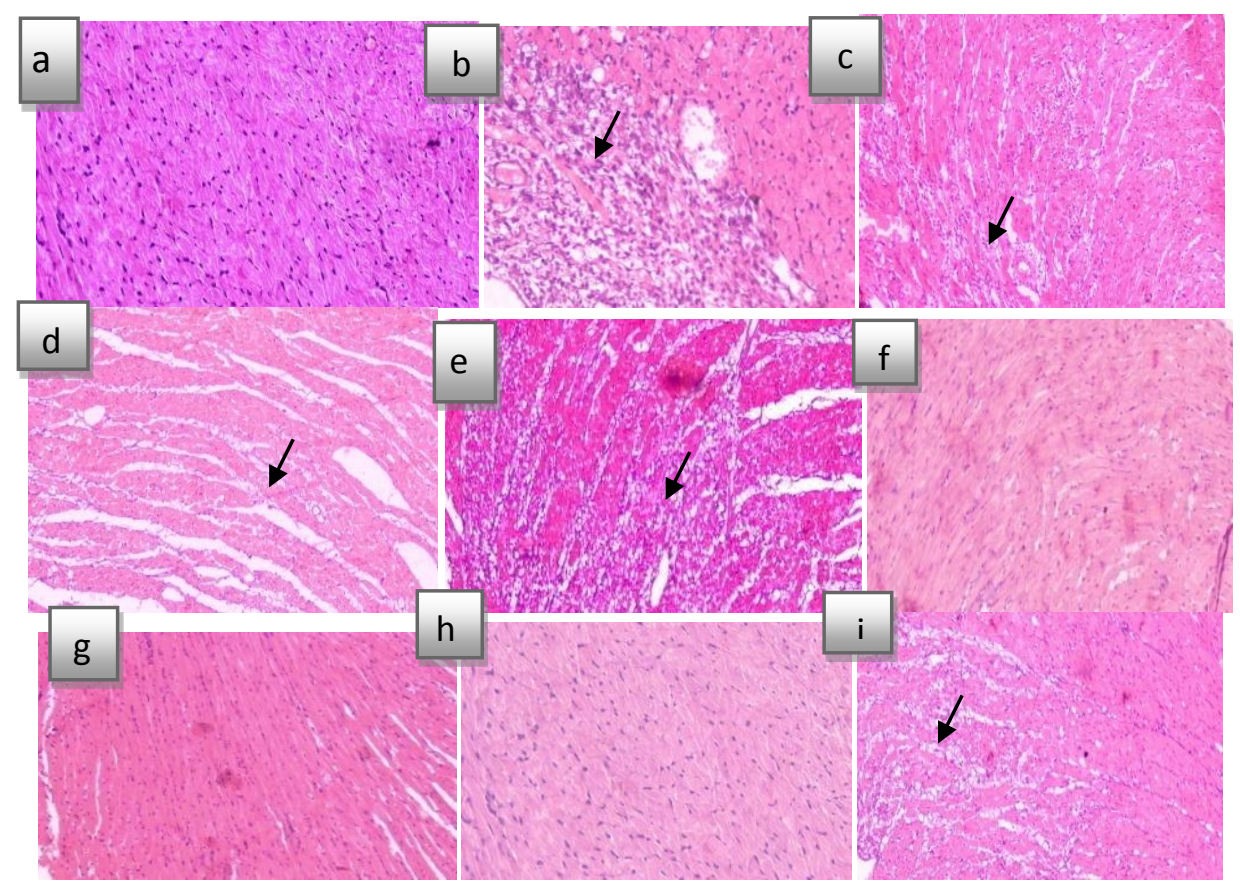

Fig. (4): Effect of pretreatment with rosuvastatin $(1,2,5,10 \& 20 \mathrm{mg} / \mathrm{kg})$, cilostazol $(18 \mathrm{mg} / \mathrm{kg})$ and combination of rosuvastatin $1 \mathrm{mg} / \mathrm{kg} \&$ cilostazol $18 \mathrm{mg} / \mathrm{kg}$ on histopathological examination of the heart. (a) normal histopathological picture of the non ischemic heart, (b) Ischemic non-treated heart showing evidence of degeneration(arrow) inflammation and extravasation of blood, (c, $d$ \&e) histopathological evidence of degeneration, inflammation of ischemic heart pretreated with rosuvastatin 1 (c), 10 (d) \& 20 (e) $\mathrm{mg} / \mathrm{kg}$, (f \& g) histopathological evidence of neither degeneration, inflammation nor extravasation of blood of ischemic heart pretreated with rosuvastatin 2 (f), $5 \mathrm{mg} / \mathrm{kg}$ (g) and combination of rosuvastatin and cilostazol (h), pretreatment with cilostazol $18 \mathrm{mg} / \mathrm{kg}$ revealed moderate improvement with focal areas of necrosis and mild infiltration of inflammatory cells (i).

3.5. Effect of rosuvastatin $(0.2-6.4 \mu \mathrm{g} / \mathrm{ml})$, cilostazol $(7.5-480 \mu \mathrm{g} / \mathrm{ml})$ and combination cilostazol $(30 \mu \mathrm{g} / \mathrm{ml})$ and rosuvastatin $(0.2-6.4 \mu \mathrm{g} / \mathrm{ml})$ on NE-induced contraction.

Addition of rosuvastatin $(0.2-6.4 \mu \mathrm{g} / \mathrm{ml})$ produced a dose dependent reduction in the height of NE-induced contraction with mean percentage reductions ranged from 1.9 \pm 1.31 to $57.2 \pm 3.43$ and were found to be statistically significant except at the dose $0.2 \mu \mathrm{g} / \mathrm{ml}$ which found to be statistically insignificant. Addition of cilostazol (15 - 480 $\mu \mathrm{g} / \mathrm{ml}$ ) produced a dose dependent decrease in the height of NE-induced contraction. The mean percentage reductions ranged from $8.79 \pm 1.84$ to $61.74 \pm 3.78$ and were found to be statistically significant. Smaller dose of cilostazol $(7.5 \mu \mathrm{g} / \mathrm{ml})$ did not produce significant reduction in NE-induced contraction. On the other hand, Addition of rosuvastatin $(0.2-6.4 \mu \mathrm{g} / \mathrm{ml})$ and cilostazol $30 \mu \mathrm{g} / \mathrm{ml}$ produced a significant decrease in the height of NE-induced contraction in a dose dependent manner with mean percentage reductions ranged from $14.0 \pm 1.35$ to $91.3 \pm 0.95$. The reductions produced by the combination more than those produced by either drug alone, Table (3) \& Fig. (5). 
Table (3): Mean \% reduction caused by rosuvastatin $(0.2-6.4 \mu \mathrm{g} / \mathrm{ml})$, cilostazol (7.5-480 $\mu \mathrm{g} / \mathrm{ml})$ and combination of rosuvastatin $(0.2-6.4 \mu \mathrm{g} / \mathrm{ml})$ and cilostazol $30 \mu \mathrm{g} / \mathrm{ml}$ on norepinephrine-induced contraction of isolated rabbit aortic spiral strip.

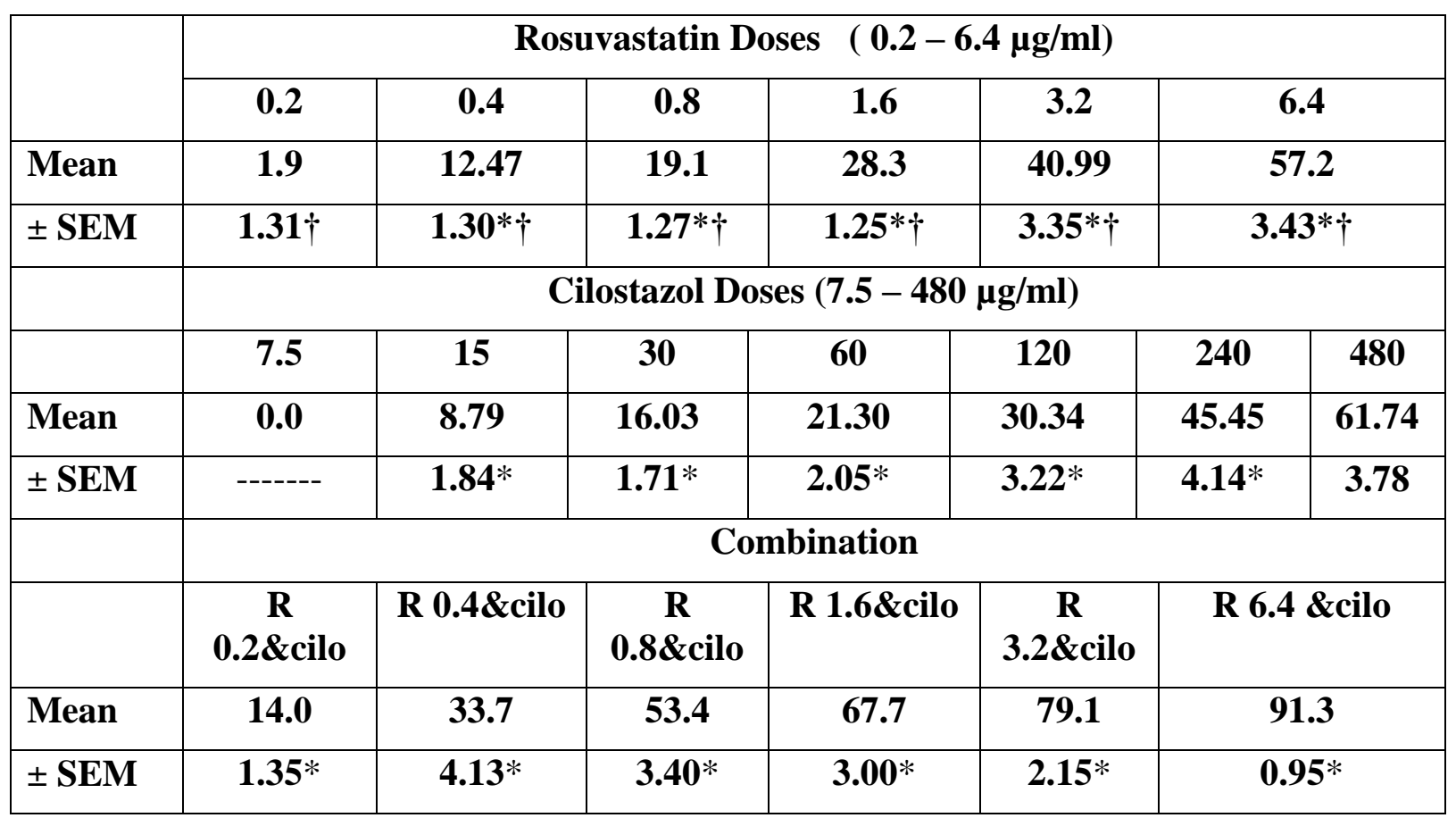

Cilo=Cilostazol $\quad *=$ Significant $\quad \uparrow=$ Significant as compared to combination
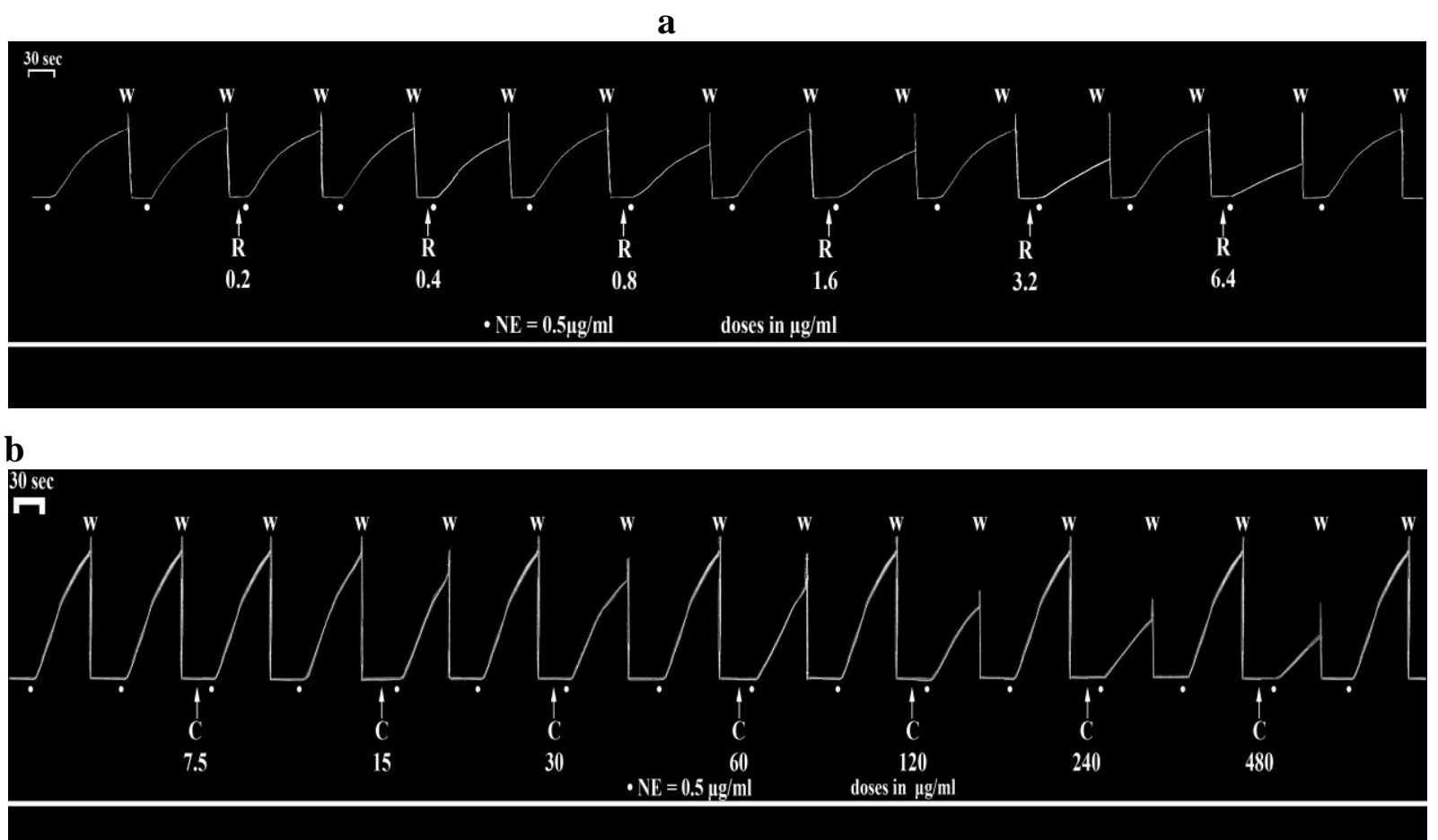


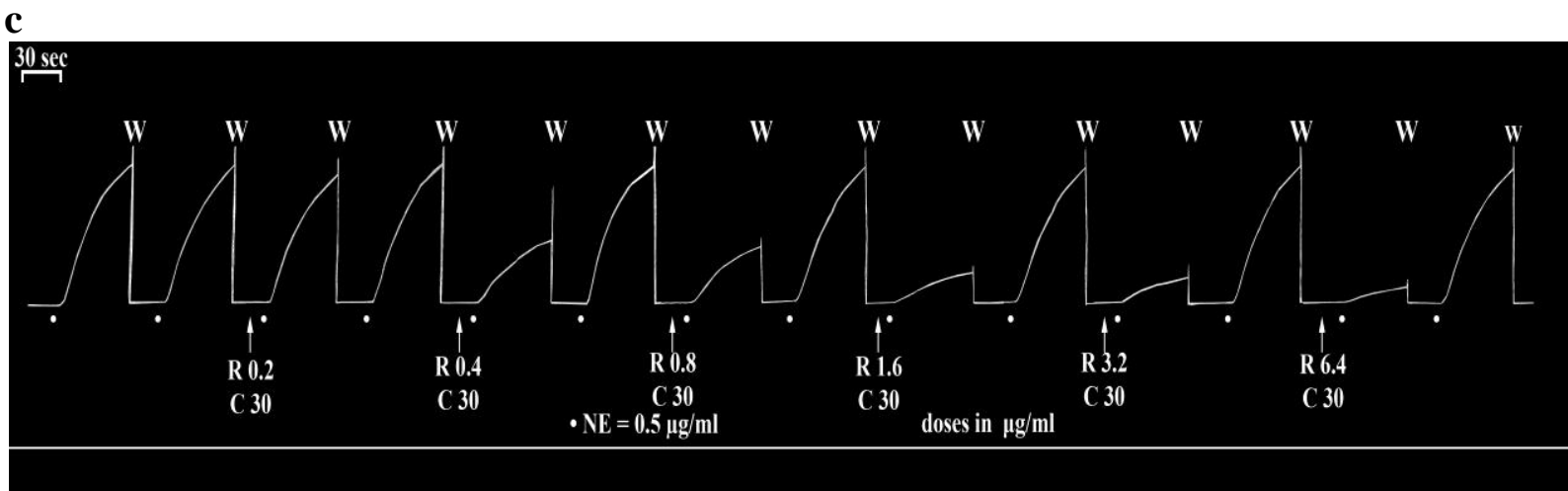

Fig. (5): Effect of rosuvastatin $(0.2-6.4 \mu \mathrm{g} / \mathrm{ml})(\mathrm{a})$, cilostazol $(7.5-480 \mu \mathrm{g} / \mathrm{ml})(\mathrm{b})$ and combination rosuvastatin $(0.2-6.4 \mu \mathrm{g} / \mathrm{ml})$ and cilostazol $30 \mu \mathrm{g} / \mathrm{ml}$ (c) on norepinephrineinduced contraction of rabbit aortic spiral strip.

$\mathrm{R}=$ Rosuvastatin $\mathrm{C}=$ Cilostazol $\mathrm{NE}=$ Norepinephrine $\mathrm{W}=$ Wash

\subsection{Site of action of either rosuvastatin or cilostazol}

The vasorelaxant effect of rosuvastatin was partially attenuated in vessels pre-incubated with L-NAME , indomethacin and glipenclamide. On the other hand, vasorelaxant effect of cilostazol was not affect by pre-incubation of aorta with indomethacin but this vasorelaxant effect was partially attenuated in vessels pre-incubated with L-NAME and glipenclamide . Fig. (6).
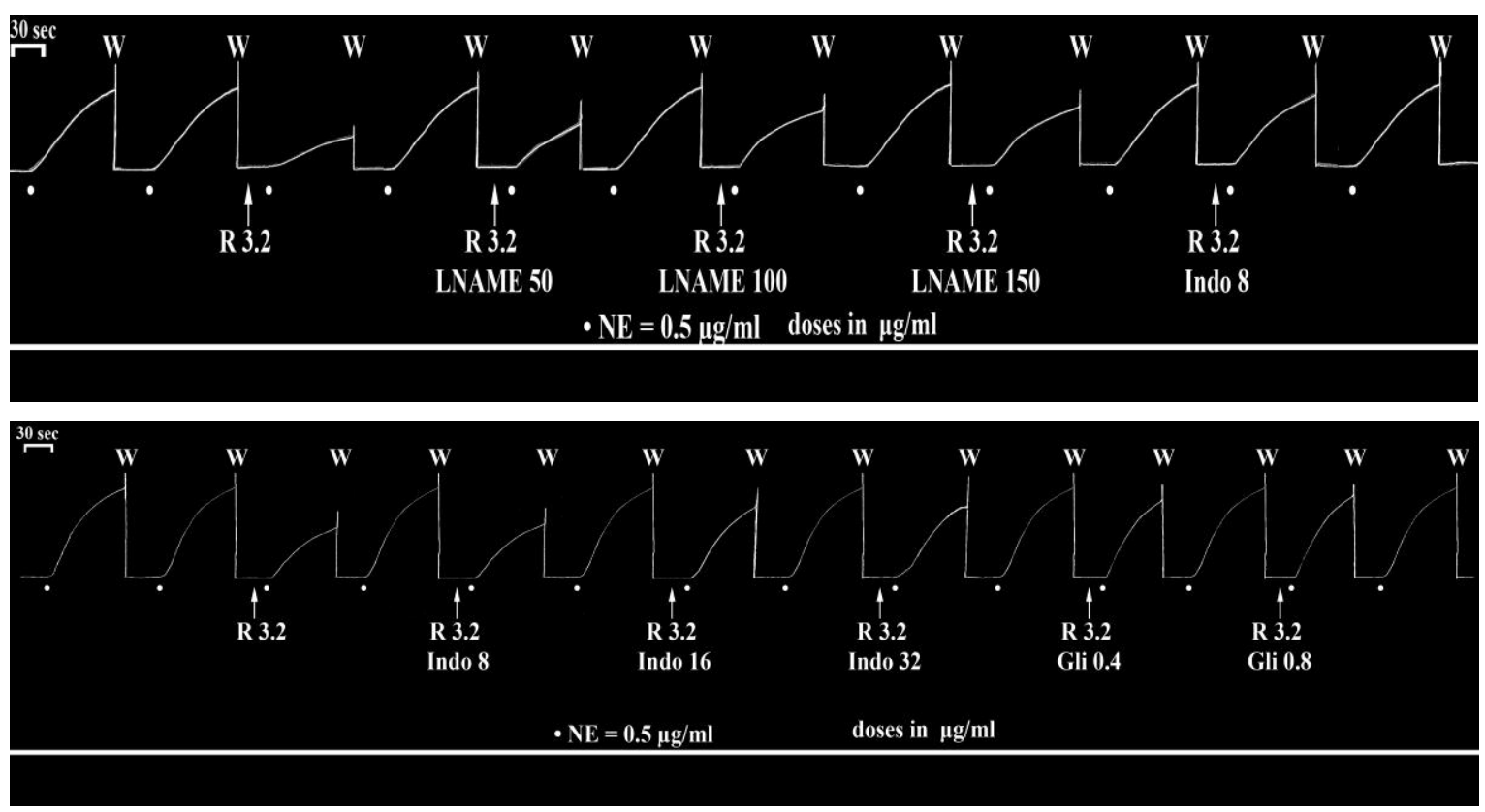

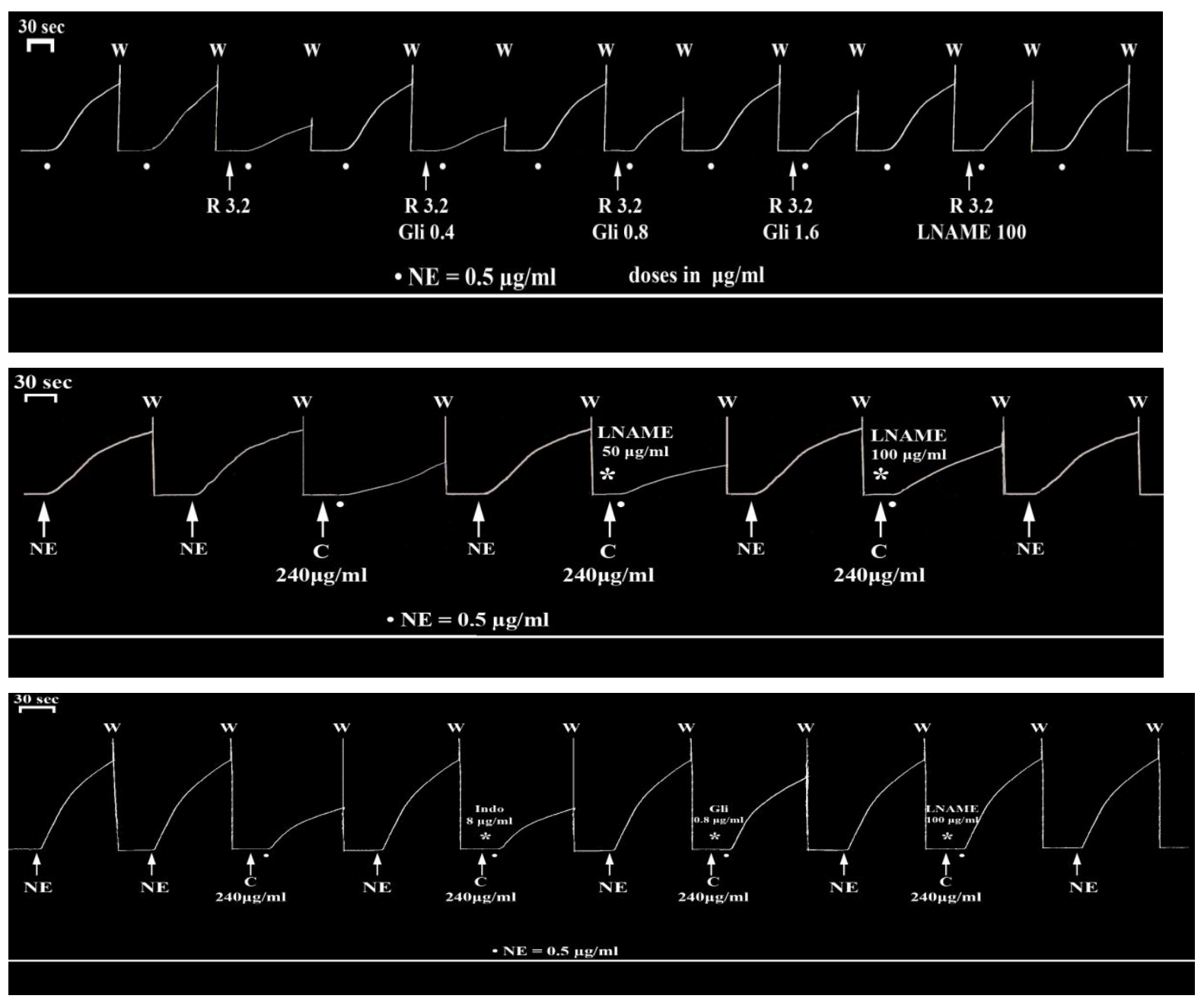

Fig. (6): Site of action of either rosuvastatin $(3.2 \mu \mathrm{g} / \mathrm{ml})$ or cilostazol $(240 \mu \mathrm{g} / \mathrm{ml})$ on isolated aortic spiral strip after pre-incubated of the aorta with L-NAME, indomethacine and glipenclamide.

$\mathrm{R}=$ Rosuvastatin $\quad \mathrm{C}=$ Cilostazol $\quad \mathrm{NE}=$ Norepinephrine $\quad$ Indo=Indomethacin Gli=Glibenclamide $\mathrm{W}=\mathrm{Wash}$

\section{Discussion}

It has been reported that isoprenaline administration in high doses to animals produces 'infarct like' lesions in the heart similar to those present in MI in humans (Lobo Filho et al., 2011). In the current study, isoprenaline was administrated to rats in the same way to produce MI and to study the effects of the drugs in that condition. Three important parameters prove the presence or absence of MI which are ECG pattern, serum and tissue biomarkers and histopathological examination (Panda et al., 2017).

In the present work. ECG tracing revealed that, isoprenaline treated group showed significant elevation of ST segment which could be due to the deleterious effects of isoprenaline on cardiac cell membrane integrity with subsequent reduced mechanical capacity of the ventricles, ST segment elevation represents the standard measure used to precisely diagnose MI in humans and animals (Thippeswamy et al., 2009). Similar 
ECG change was also reported in previous studies (Zaafan et al., 2013 and AboGresha et al., 2014).

ECG tracing also revealed that, isoprenaline treated group showed significant decreased in heart rate. This result is in agreement with that of Dhakad et al. (2017). On the contrary, panda et al. (2017) found that, heart rate was significantly increased in isoprenaline treated albino rats. This controversy may be explained on the basis of species variation, or difference in isoprenaline dose and duration of treatment.

Additionally, myocardial injury was further manifested in the present study by the significant elevation of $\mathrm{CK} \mathrm{MB}$ and $\mathrm{LDH}$ levels which is accordance with previous reports by Zhang et al. (2014) and panda et al. (2017). These cytosolic enzymes serve as sensitive indices to assess the severity of myocardial infarction. Increased activities of these marker enzymes in the serum are indicative of leakage of them from the heart as a result of cellular damage and loss of functional integrity and/ or permeability of cell membrane ( $\boldsymbol{L i}$ et al., 2012). Inflammation is also a key process involved in mediating myocardial tissue damage after an ischemic event. It was reported that, ISO stimulation induces myocardial proinflammatory cytokine TNF- $a$ and IL-1 $\beta$ expressions (Feng and $\mathbf{L i}$, 2010). In the present study, isoprenaline produced an increase in the serum levels of CRP an effect that is in accordance with the study of Zaafan et al. (2013). CRP has been defined as a sensitive but nonspecific marker of inflammation. Therefore, CRP assay is considered useful in predicting coronary risk (Shrivastava et al., 2015).

In the current study, increased oxidative damage by isoprenaline was shown by markedly increased lipid peroxidation product; MDA. There was also decrease of the activity of the antioxidants SOD and catalase. These findings are consistent with previous reports (Goyal et al., 2015 , Panda et al., 2017).

Cardiac damage was further confirmed in the present work by the histopathological examination of the cardiac tissue that revealed the presence of marked myofibrillar degeneration with infiltration of inflammatory cells, interstitial edema and extravasation of blood. Similar results have been reported by Zhang et al . (2014). Toutounchi et al. (2017) also showed that, the lesion induced by isoprenaline characterized by higher degree of myocardial cell swelling, degeneration, loss of transverse striations, and large numbers of infiltrating inflammatory cells.

In this work, rosuvastatin was given to rats in doses ranging from $1-20 \mathrm{mg} / \mathrm{kg}$ as pretreatment for two weeks before induction of ischemia. The different doses showed different degree of protection against isoprenaline-induced cardiac ischemia. It was observed from the present study that, pretreatment with rosuvastatin in doses of 2 or $5 \mathrm{mg} / \mathrm{kg}$ decreased the elevated levels of $\mathrm{CK} \mathrm{MB}, \mathrm{LDH} \& \mathrm{CRP}$ in ischemic rats to nearly the normal values of non ischemic rats and were significantly equal in this respect. These effects indicate that, rosuvastatin could preserve the structural and functional integrity and/or permeability of the cardiac membrane and thus restricting the leakage of these indicative enzymes from the myocardium. Rosuvastatin treatment showed also increase in antioxidants catalase, SOD and a significant decrease in heart MDA content which are collectively may be attributed to increased antioxidants calalase and SOD activity which was observed in this work. In addition, histopathology of cardiac tissue confirmed this effect which was the best with the doses of $2 \& 5 \mathrm{mg} / \mathrm{kg}$. The current results are in harmony with those reported by Elhemely et al. (2014). and Yu et al. (2018). 
In accordance with results of the present work, several clinical studies using different doses of rosuvastatin confirmed its cardioprotective benefit (Mannacio et al., 2008, Yun et al., 2009 and Pan et al., 2015). More recently, Ye et al. (2017) compared the cardioprotective effect of two doses $(10 \& 20 \mathrm{mg})$ of rosuvastatin given before percutaneous coronary intervention (PCI). These doses are corresponding to doses $1 \& 2 \mathrm{mg} / \mathrm{kg}$ which are used in present work. The authors found that, the loading dose of $20 \mathrm{mg} /$ day of rosuvastatin could significantly reduce the level of CRP after PCI. In addition, the levels of LDL-C and serum troponine $\mathrm{T}$ of the high-dose group were significantly lower than the conventional dose group.

However, in the present study pretreatment of rats with rosuvastatin in high dose of $20 \mathrm{mg} / \mathrm{kg}$ did not produce any significant protection against ISO-induced myocardial damage. This result is consistent with that reported by Liu et al. (2017) who attributed failure of cardioprotective effect with high dose of rosuvastatin to aggressive inhibition of HMG-CoA reductase enzyme. This is explained on the bases that, statins reduce not only cholesterol biosynthesis but also the production of many metabolites distal to mevalonic acid, such as dolichols, prenylated proteins, and coenzyme Q10. Coenzyme Q10 is considered to be crucial for energy transduction in mitochondria, and the inhibition of its synthesis may be responsible for myocardial death associated with high doses of rosuvastatin treatment as a result of mitochondrial damage.

In the present study, pretreatment of ischemic rats with cilostazol $18 \mathrm{mg} / \mathrm{kg}$ either alone or in combination with rosuvastatin $1 \mathrm{mg} / \mathrm{kg}$ decreased ST segment elevation, increased heart rate, produced a significant decrease in serum levels of elevated CK MB, LDH \& CRP in ischemic rats. The combination showed excellent protection against cardiac damage with signs of improvement in heart with nearly normal heart rate, also decreased the elevated CK MB, LDH \& CRP in ischemic rats to nearly the normal values of normal non ischemic rats. This improvement was almost similar to that produced by rosuvastatin at doses $2 \& 5 \mathrm{mg} / \mathrm{kg}$. This changes in ECG, cardiac enzymes and CRP were coupled by a reduction in lipid peroxidation in heart tissue through the significant decrease in heart MDA content and increased antioxidant calalase and SOD activities. In addition, the histopathological picture of pretreated groups showed less inflammation and myonecrosis than non treated ischemic rats. These results are in agreement with a recent study done by Dhakad et al. (2017) who reported that, pretreatment of ischemic rats with cilostazol $(5.8 \mathrm{mg} / \mathrm{kg})$ for five days significantly reduce the level of diagnostic marker enzymes, LDH and CK MB with significant reduction of infarction size. In addition, cilostazol treated rats showed the signs of improvement in heart with the outcome of nearly normal ST wave pattern, prevented the decrease in heart rate, thereby decreased workload and facilitated the heart to maintain myocardial oxygen balance in ischemic tissues.

As regard experiments on isolated rabbit aortic spiral strips, rosuvastatin at doses ranged from $0.4-6.4 \mu \mathrm{g} / \mathrm{ml}$ caused a significant dose-dependent reduction in NE-induced contraction. The vasorelaxant effect of rosuvastatin is in agreement with other study by Lopez-Canales et al. (2015) who found that, rosuvastatin elicited a concentrationdependent relaxation in endothelium intact and denuded phenylephrine-precontracted aortic rings.

The vasorelaxant effect of rosuvastatin in the present study was partially attenuated in vessels pre-incubated with L-NAME, indomethacin or glipenclamide 
indicating that, endothelial nitric oxide (NO), prostaglandin and ATP-sensitive $\mathrm{K}$ channel are involved in its vasorelaxant effects. These results are in agreement with the study done by Lopez-Canales et al. (2011) and Lopez-Canales et al. (2015).

As regard the vasorelaxant effect of cilostazol, a small dose $(7.5 \mu \mathrm{g} / \mathrm{ml})$ had no effect while at doses ranged from $15-480 \mu \mathrm{g} / \mathrm{ml}$ a significant dose-dependent reduction in NEinduced contraction of isolated rabbit aortic spiral strip was found. This result is similar to other studies which reported that, cilostazol caused a concentration dependent relaxation of the rat aortic rings precontracted with serotonin (5-HT) (Nurullahoglu-Atalik et al., 2012) or phenylephrine (Li et al., 2015).

The vasorelaxant effect of cilostazol in the present study was partially attenuated in vessels pre-incubated with L-NAME and glipenclamide indicating that, endothelial NO, ATP-sensitive K channel are involved in its vasorelaxant effects. On the other hand vasorelaxant effect was the same in vessels pre-incubated with indomethacin indicating that, PG may be not involved. These results are in agreement with the study done by $\boldsymbol{L i}$ et al. (2015).

Administration of a combination of rosuvastatin $(0.2-6.4 \mu \mathrm{g} / \mathrm{ml})$ and cilostazol $30 \mu \mathrm{g} / \mathrm{ml}$ produced a significant decrease in the height of NE-induced contraction in a dose dependent manner. In the present study, combination of rosuvastatin and cilostazol $(30 \mu \mathrm{g} / \mathrm{ml})$ produced significantly higher vasorelaxant than that produced by rosuvastatin alone. Similar result has been reported by Nurullahoglu-Atalik et al. (2017) who found that, in the presence of cilostazol, atorvastatin induced relaxation of rat aortic rings precontracted with phenylephrine at lower concentrations that atorvastatin alone. The authors concluded that, treatment with cilostazol significantly enhanced the potency of atorvastatin.

\section{Conclusion}

It is concluded that, rosuvastatin, cilostazol or combination caused a cardioprotective effect against experimentally-induced myocardial infarction. we showed that low dose rosuvastatin ( $1 \mathrm{mg} / \mathrm{kg} /$ day) combined with cilostazol (18 $\mathrm{mg} / \mathrm{kg} / \mathrm{day}$ ) has more cardioprotective effect than either drug alone, which make the combination is a good alternative to more larger doses of rosuvastatin. The beneficial role of rosuvastatin and cilostazol in the experimental setting of myocardial infarction would surely open new gates in the treatment of patients presented with coronary heart disease. The acute in vitro application of rosuvastatin cilostazol or their combination to NE-precontracted aortic strips had a vasorelaxant effect.

\section{REFERENCES}

Abdikarim A and Basgut B. (2016): An Evidence-Based Review of Pain Management in Acute Myocardial Infarction. J Cardiol Clin Res; 4(4):1067.

Abo-Gresha NM, Abel-Aziz EZ, Greish SM. (2014): Evening primrose oil ameliorates platelet aggregation and improves cardiac recovery in myocardial-infarct hypercholesterolemic rats. Int $\mathrm{J}$ Physiol Pathophysiol Pharmacol; 6:23-36.

Bai Y, Muqier, Murakami H, Sumi S, Yamada Y, Ushikoshi H, et al. (2011): Cilostazol protects the heart against ischemia reperfusion injury in a rabbit model of myocardial infarction: Focus on adenosine, nitric oxide and 
mitochondrial ATP- sensitive potassium channels. Clin Exp Pharmacol Physiol J; 38 (10):658-665.

Balakumar P, Mahadevan N. (2012): Interplay between statins and PPARs in improving cardiovascular outcomes: a double-edged sword? Br J Pharmacol; 165:373-379.

Caliborne A. (1985): Assay of catalase, in handbook of methods of oxygen radical research; edited by RA Greenwald (CRC Press, London, UK, Boca Raton (USA);283.

Dhakad PK, Sharma PK, Kumar S, Sharma AK, Mishra R, Weisser, Dixit A. (2017): Cardio Protective Action of Cilostazol, Milrinone and Their Combination over Isoproterenol Induced Myocardial Infarction in Wistar Rats. International Journal of Cardiovascular and Cerebrovascular Disease; 5(1): 8-14.

Dourado PMM, Tsutsui JM, Landim MBP, Filho AC, Galvao TFG. (2011): Rosuvastatin prevents myocardial necrosis in an an experimental model of acute myocardial Infarction. Braz J Med Biolo Res; 44:496-476.

Elhemely MA, Omar HA, Ain-Shoka AA, Abd El-Latif HA, Abo-youssef AM, EL Sherbiny GA. (2014): Rosuvastatin and ellagic acid protect against isoprenaline-induced myocardial infarction in hyperlipidemic rats. Beni-Suef University J Basic and Applied Sci; 3(4):239-246.

Ervan B, Karpuzoglu H, Develi S, Kalaz EB, Soluk-Tekkesin M, Olgac V, et al. (2014): Effects of carnosine on prooxidante-antioxidant status in heart tissue, plasma and erythrocytes of rats with isoproterenol-induced myocardial infarction. Pharmacol. Rep; 66:81-86.

Feng W, Li W. (2010): The study of ISO induced heart failure rat model Exp Mol Pathol; 88(2): 299-304.

Goyal SN, Sharma C, Mahajan UB, Patil CR, Agrawal YO, Kumari S, et al. (2015): Protective Effects of Cardamom in isoprenalin-induced myocardial infarction in rats. Inter J Mol Sci; 16: 27457-27469.

Habibi J, Whaley-Connel A, Qazi MA, Hayden MR, Cooper SA. (2007): Coenzyme A Reductase Inhibitor, Decreases Cardiac Oxidative Stress and Remodeling in Ren2 Transgenic Rats. Endocr; 148(5):2181-2188

Hutchinson WL, Koenig W, Frolich M, Snd M, Lowe GD, Pepys MB. (2000): Immnoradiometric assay of circulating C-reactive protein: age-related values in adult general population. Clin Chem; 46:934-938.

King J. (1965): The dehydrogenase or oxidoreductase lactate dehydrogenase in Practical Clinical Enzymology In: Van D(ed.), Van Nostrand, London; PP:93-193.

Li H, Xie Y, Yang Q, Wang S, Zhang B, et al. (2012): Cardioprotective Effect of Paeonol and Danshensu Combination on Isoproterenol-Induced Myocardial Injury in rats. PLOS ONE; 7(11): e48872.

Li H, Hong DH, Son YK, Na SH, Jung W, Bae YM, et al. (2015): Cilostazol induces vasodilation through the activation of $\mathrm{Ca}^{2+}$-activated $\mathrm{K}^{+}$in aortic smooth muscle. Vascular Pharmacol; 70:15-20. 
Liu CW, Fan Yang F, Cheng SZ, Yue Liu Y, Wan LH, Cong HL.(2017): Rosuvastatin postconditioning protects isolated hearts against ischemiareperfusion injury: The role of radical oxygen species, PI3K-Akt-GSK-3 $\beta$ pathway, and mitochondrial permeability transition pore. Cardiovasc Therap; 35:3-9.

Lobo Filho HG, Ferreira NL, Bezerra de Sousa R, Carvalho E, Lobo PL, Lobo Filho J.(2011): Experimental model of myocardial infarction induced by isoproterenol in rats. Rev Bras Cir Cardiovasc; 26(3):469-76.

Lopez-Canales JS, Lozano-Cuenca J, Lopez-Canales OA, Aguilar-Carrasco JC, Aranda-Zepeda L, et al. (2015): Pharmacological characterization of mechanisms involved in the vasorelaxation produced in aortic rings from rats with a cafeteria-style diet. Clinical and Experimental Pharmacology and Physiology; 42: s653-s661.

López-Canales JS, López-Sanchez P, Perez-Alvarez VM, Wens-Flores I, Polanco AC, et al. (2011): The methyl ester of rosuvastatin elicited an endotheliumindependent and 3-hydroxy-3-methylglutaryl coenzyme A reductaseindependent relaxant effect in rat aorta. Braz J Med Biol Res; 44(5):438-444.

Mannacio VA, Iorio D, De Amicis V, Di Lello F, Musumeci F. (2008): Effect of rosuvastatin pretreatment on myocardial damage after coronary surgery: A randomized trial. J Thorac Cardiovasc Surg; 136(6):1541-1548.

Marklund S and Marklund G. (1974): Involvement of superoxide anion radical in the autooxidation of pyrogallol and a convenient assay for superoxide dismutase. Eur $\mathbf{J}$ Biochem ; 47:469-474.

Nurullahoglu-Atalik KE, Okudan N, Belviranli M, Gokbel H, Simsek L. (2012): Curcumin increases vasodilatory effect of cilostazol in diabetic rat aorta. Ind J Exper Biol ;128-132

Nurullahoglu-Atalik KE, Kutlu S, Solak H, Koca RO. (2017): Cilostazol enhances atorvastatin-induced vasodilation of female rat aorta during aging. Physiol Int ;3:226-234.

Okinaka S, Kumagai H, Ebashi S, Sugita H, Momoi H, Toyokura Y, Fujie Y. (1961): Serum creatine phosphokinase activity in progressive muscular dystrophy and neuromascular diseases. Arch Neurol ;4:250-255.

Ohkawa H, Ohishi N, Yagi K. (1979): Assay for lipid peroxides in animal tissue by thiobarbituric acid reaction. Ana Biochem ;95:351-358.

Pan Y, Tan Y, Li B, Li X. (2015): Efficacy of high-dose rosuvastatin preloading in patients undergoing percutaneous coronary intervention: a meta analysis of fourteen randomized controlled trials. Lipids Health Dis ;14:97.

Paget GE, and Barnes JM. (1964): Toxicity tests, In: Evaluation of drug activities pharmacometrics, edited by Laurence, D.R. and Bacharach, A.L., Vol. 1 Chapter 6, P. 135. Academic Press, London and New York.

Panda S, Kar A, Biswas S. (2017): Preventive effect of Agnucastoside C against Isoproterenol-induced myocardial injury. Sci Rep ; 7: 16146. 
Rondi S, Peddolla R, Venisetty R. (2014): Neuro, cardio, and reno protective activities in streptozotocin-induced type 2 diabetic rats undergoing treatment with metformin and glimepiride. J Adv Pharm Technol Res;5:78.

Shrivastava AK, Singh HV, Raizada A, Singh SK. (2015): C-reactive protein, inflammation and coronary heart disease. Egyp Heart $\mathrm{J} ; 67: 89-97$.

Thippeswamy B, Thakker S, Tubachi S, Kalvani G, Netra M, Patil U, et al. (2009): Cardioprotective effect of Cucumis trigonus Roxb on isoproterenol-induced myocardial infarction in rat. Am J Pharmacol Toxicol ;4:29-37.

Toutounchi NS, Afrooziyan A, Rameshrad M, Rezabakhsh A, vaez $\mathbf{H}$, et al. (2017): Cardioprotective Effects of Rosmarinic Acid on IsoproterenolInduced Myocardial Infarction in Rats. Pharm Sci ;23:103-111.

Xue Han MM, Yi Zhang BS, Lin Yin MM, Lin Zhang MM, Yue Wang BS, et al. (2018): Statin in the treatment of patients with myocardial infarction. A meta-analysis. Medicine (Baltimore); 97(12): e0167.

Ye Z, Lu H, Sul Q, Guo W, Dail W, Li H. (2017): Effect of high-dose rosuvastatin loading before percutaneous coronary intervention in Chinese patients with acute coronary syndrome: A systematic review and meta analysis. PLOS ONE ;12(2): e0171682.

Yu Y, Jin L, Zhuang Y, Hu Y, Cang J, Guo K. (2018): Cardioprotective effect of rosuvastatin against isoproterenol-induced myocardial infarction injury in rats. Inter J Mol Med ;41(6):3572.

Yun KH, Jeong MH, Oh SK, Rhee SJ, Park EM, Lee EM, et al. (2009): The beneficial effect of high loading dose of rosuvastatin before percutaneous coronary intervention in patients with acute coronary syndrom. Inter J Cardio ;137:246-251.

Zaafan MA, Zaki HF, El-Brairy AI, Kenawy SA. (2013): Protective effects of atorvastatin and. Quercetin on isoprenaline-induced myocardial infarction in rats. Bulletin of Faculty of Pharmacy, Cairo University; 51:35-41.

Zhang T, Yang S,Du J. (2014): Protective effects of Berberine on IsoproterenolInduced Acute Myocardial Ischemia in Rats through regulating HMGB1TLR4 Axis. Evidence-Based Complementary and Alternative Medicine.2014:849783. 


\section{الملخص العربى \\ تأثير دواء روزوفاستاتين فى حالة نقص تزوية القلب المستحدث معمليا و على تفاعلية الثريان الثلأورطى.

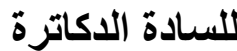

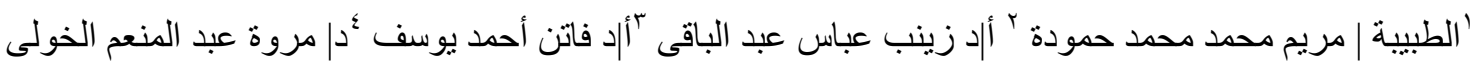

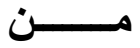

'مدرس مساعد بقسم الفار ماكولوجىـ كلبة الطب(بنات)- جامعة الأزهر 'أستاذ بقسم الفارماكولوجىـ كلية

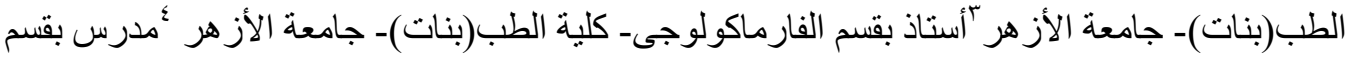

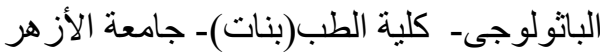

لا يز ال احتشاء عضلة القلب (MI) يمثل مشكلة صحية عامة كبرى في العالم. هدفت الدر اسة الحالية إلى الى القي

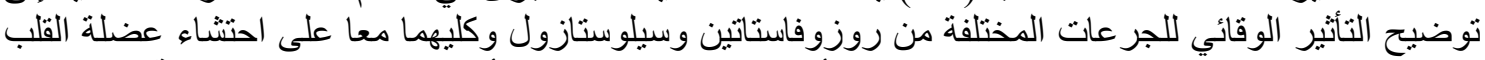

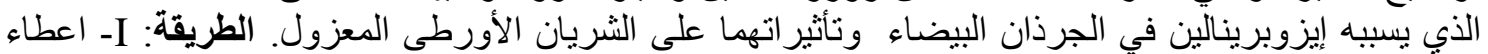

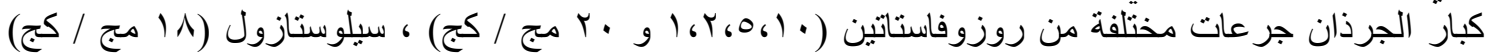

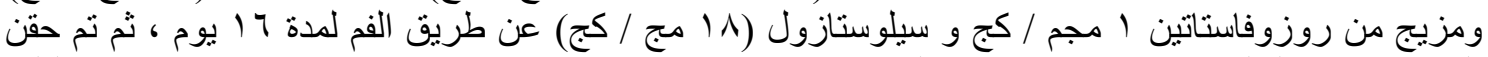

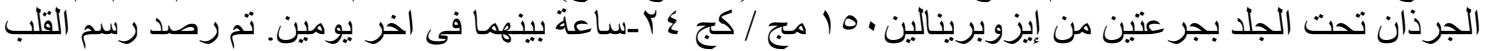

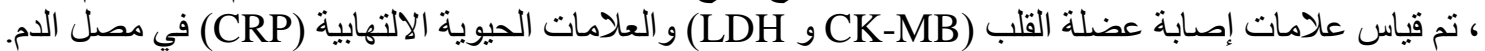

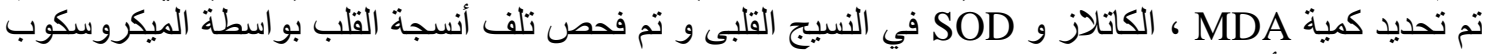

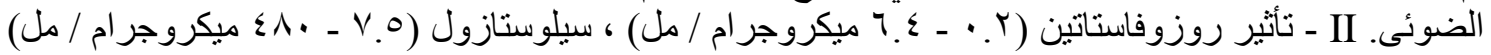

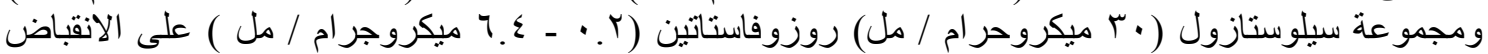

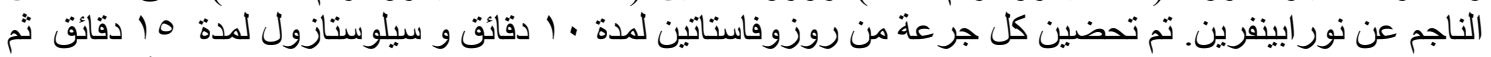

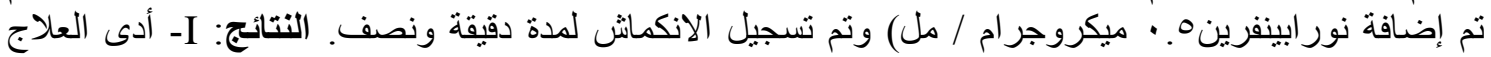

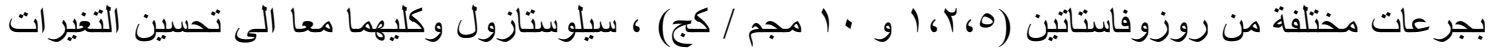

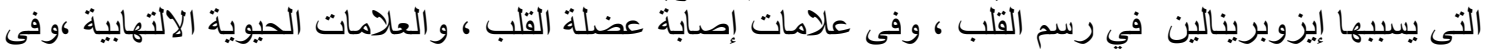

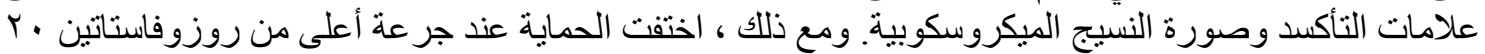

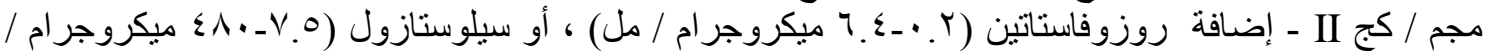

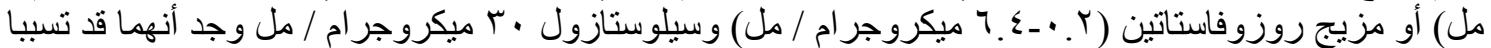

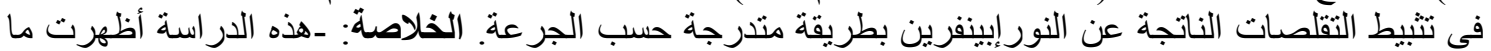

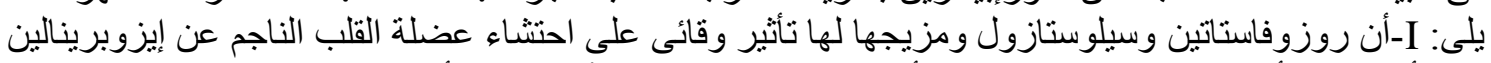

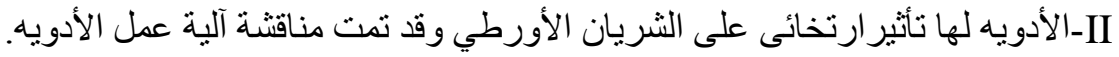

